\title{
AN ENCOUNTER BETWEEN BLACK THEOLOGY AND REFORMED THEOLOGY: THE INVOLVEMENT OF GOVENDER, MAZAMISA, MOFOKENG AND NTOANE
}

\section{Nico Botha}

Department of Christian Spirituality, Church History and Missiology University of South Africa

bothana@unisa.ac.za

\section{ABSTRACT}

During the nineteen eighties numerous meaningful booklets were published by Christian groups on social analysis and against an apartheid society. Less known, but extremely powerful, four black Dutch Reformed theologians wrote similar sophisticated doctorate theses. This article delineates the gist of these messages to honour Takatso Mofokeng. The urgent question is also whether these alarming analyses and bone-cutting witnesses would be relevant for the contemporary situation regarding the horrific violence, un-arrested poverty, unemployment, rampant 'official' theft and crime. The outcome is that this type of hermeneutics keeps the dream of freedom alive and rekindles hope towards renewal.

Keywords: Black theology; Reformed theology; Takatso Mofokeng; Kekuha Ntoane; Llewellyn Mazamisa; S.P. Govender

\section{INTRODUCTION: TODAY THESE SCHOLARS ARE STILL REVELEVANT}

The purpose of the investigation is whether creative and innovative discourses have emerged in the encounter between black theology and Reformed theology. To avoid a broad and general discussion, and becoming too vague, the research is restricted

\section{UNISA $\cong$}

Studia Historiae Ecclesiasticae Volume 41 | Number 2 | 2015 pp. $69-78$
DOI: http://dx.doi.org/10.17159/2412-4265/2015/347 Print ISSN 1017-0499 | Online 2412-4265 (c) 2015. Studia Historiae Ecclesiasticae 
to four theologians from the black Dutch Reformed Churches, Doctors Govender, Mazamisa, Mofokeng and Ntoane. They were members of the Belydende Kring, (the Confessing Circuit), a confessing movement of Christians from the black Reformed churches who struggled against apartheid in church and society. A further issue is that all four have studied at different times in the Netherlands, which is arguably the hub of Reformed theology. The very interesting feature about these four is that in different degrees and perspectives they could be identified conclusively as proponents of black theology. This combination of being Reformed as well as espousing black theology is essentially the question addressed in the article. The primary sources to be investigated are the theses which they produced at the Theologische Hogeschool in Kampen in the Netherlands under the supervision of different Dutch scholars. An interesting fact is that for Mofokeng and Ntoane, in chronological order, the 'defence of thesis' occurred very close to one another in September and October 1983 respectively, and for Mazamisa and Govender in June and December 1987 respectively. This was indeed a very productive time in South Africa as far as theological responses and literature against apartheid were concerned. This is the period which saw the emergence of documents, for example, The Kairos Document ${ }^{1}$, The Evangelical Witness in South Africa ${ }^{2}$, The Confession of Belhar ${ }^{3}$, and indeed quite a few ground-breaking publications on black theology, for example, The Unquestionable Right to be Free. ${ }^{4}$

The most significant underlying assumption of the article is that all four contributed creatively and innovatively to black theology in a manner that may still have some relevance 25 to 30 years down the line. In a real sense the mere titles of their theses capture something of the relevance there may still be in what they intended to expound way back in the nineteen eighties. Inevitably the article will reflect wariness of two important issues: First, there is the ongoing and nagging debate, or lack thereof, of the redundancy of black theology. Second, there is a distinct difference in context between the South Africa of the nineteen eighties and that of post-1994. Be that as it may, their titles: A Cry for Life; The Crucified amongst the Crossbearers; Beatific Comradeship; and In Search of Tomorrow, reflect a great deal

1 The Kairos Document. 1985. This document emerged as a prophetic response to the crisis of apartheid. In it the cheap and problematic theologies of reconciliation and of state are exposed. In reaction to this; a prophetic theology with its social analytical, hermeneutic and praxis oriented mediation.

2 The Evangelical Witness. 1986. This document saw the light as a response of Evangelical Christians in South Africa to apartheid. Apart from being Evangelical, it differs from the Kairos Document in that it contains a great measure of self-criticism.

3 The Confession of Belhar. 1986. The Confession initially appeared as a concept document in October 1982 and after a period of testing with the congregations of the former Dutch Reformed Mission Church, was adopted as part of the body of Confessions in October 1986. The key words of the Confession are unity, reconciliation, justice and obedience.

4 The Unquestionable Right to be Free. 1987. The book is a compilation of essays on black theology by South African proponents of this brand of liberation theology. 
of the prevailing quest, hic et nunc, for a society that is qualitatively different. In the wake of the most horrific violent attacks against women and children in the country, the worsening labour situation, indeed, the as yet un-arrested triad of inequality, poverty and unemployment, the titles alluded to appear like slogans on the placards of protestors.

\section{THE STRUCTURE OF THE APPROACH}

The article is organised as follows: First, each of the four will pass the revue in terms of a description and analysis of its distinctive contribution to black theology. The ideas of Mofokeng will come in for a more extensive treatment since this essay is written in his honour. Briefly for now, if they are taken in chronological order, Ntoane contributed by interpreting and appropriating specific tenets of Reformed theology to the context of suffering and oppression of black South Africans; Mofokeng offered a very creative black Christology; Mazamisa put a creative spin on the notion of comradeship; and Govender brought black theology into a critical discourse with Marx and Gramsci. Second, an attempt will be made at crystallising what in their thinking may still be relevant in the absence or presence of black theology. Thirdly, a brief proposal is presented on creative hermeneutics emanating from the thoughts of Ntoane, Mofokeng, Mazamisa and Govender and how they have enriched the search for 'home grown' epistemologies.

\section{CREATIVE DISCOURSES IN THE ENCOUNTER BETWEEN REFORMED THEOLOGY AND BLACK THEOLOGY}

\section{L.R. Kekuha Ntoane: A Cry for Life ${ }^{5}$}

The most creative moment in Ntoane's theological reflection in his thesis titled, $A$ Cry for Life. An Interpretation of 'Calvinism' and Calvin, is the following question: Does the work of Calvin have any significance for black Christians participating in the struggle for liberation? To see the richness of the manner in which the author was answering the question, one should have had space to dwell on the engagement of Ntoane with Johan Heyns, whom he critiques for his 'Calvinism', namely an almost legalistic, but indeed a technical interpretation of Calvin that is entirely divorced from real human life. What must suffice, however, is a brief look at Ntoane's ${ }^{6}$ interpretation of Calvin's theology as an instrument for the black liberation struggle.

5 L.R. Kekuha Ntoane, A Cry for Life. An Interpretation of 'Calvinism' and Calvin, 1st ed. (1983).

6 Ntoane, A Cry for Life, 252-258. 
Earlier on in his thesis he formulated the creative moment in the encounter between Calvin's theology and a black theology of liberation as follows: '...the validity of Calvin's theology in so far as it responds to the aspirations of the Black oppressed people of South Africa.' 7

Let us now turn to some salient aspects of Calvin's theology which can contribute to a black theology of liberation, according to Ntoane's interpretation.

First, in the area of consciousness, Ntoane ${ }^{8}$ identifies the so-called duplex cognitio as a fruitful element within Calvin. The argument about the duplex cognitio proceeds approximately as follows: Knowledge has a relational character and human beings know, because of God's openness to them. In this 'relational knowledge', consciousness is a basic component. Ntoane proceeds to show that the consciousness which arises from such knowledge is a positive consciousness. It enables human beings to arrive at a self-definition that is not based on foreign standards, but actually through self-recognition and consciousness of their own situation. The consequences for a black theology of liberation, according to Ntoane, is that theologians can engage in programmes of 'conscientisation' in the knowledge that self-consciousness is basic to people's relationships with God. 'Consciousness', asserts Ntoane, 'is a humanising and liberating activity, one in which man [sic.] is freed - liberated from self and others. ${ }^{9}$

Second, Calvin's ethical-religious epistemology can contribute to a struggle for liberation. For Calvin, ethical-religious knowledge is not metaphysical or abstract, but knowledge in a historical and existential reality. In Ntoane's ${ }^{10}$ interpretation, 'It is praxis orientated knowledge...one which seeks to live up to the rudiments of the gospel of Christ, namely justice, love, peace...' It is the type of knowledge, if Ntoane's interpretation of Calvin is understood correctly, which overcomes dependence as a result of oppression.

Thirdly, in calling Calvin's basic theological conception Christopneumatological, Ntoane ${ }^{11}$ latches on to a very basic Calvinist theological premise, which professes that the entire human race owes its existence to God. According to this all life is dependent on God in the most basic forms, for example, the sun that shines on human beings, the air we breathe, the bread we eat and the water we drink. Consequently, all people are equal in their dependence on God. Any theology of liberation that accepts such a basic truth will find support in Calvin's theology.

Fourth, a final aspect of Calvin's theology, which for Ntoane could be fruitful for a liberation struggle, is the notion of discontinuity. Ntoane proceeds to elaborate how Calvin's doctrine of justification, which delineates re-creation, a new beginning

$\begin{array}{ll}7 & \text { Ntoane, A Cry for Life, } 245 . \\ 8 & \text { Ntoane, A Cry for Life, } 253 . \\ 9 & \text { Ntoane, A Cry for Life, } 253 . \\ 10 & \text { Ntoane, A Cry for Life, } 254 . \\ 11 & \text { Ntoane, A Cry for Life, } 254 .\end{array}$ 
of a novel life and of liberation, can contribute to a theology of liberation. The discontinuity in conjunction with justification renders everything and everybody changeable. Nothing is untouchable and human beings should in fact be continuously active with the shaping of society.

\section{T.A. Mofokeng - The Crucified among the Crossbearers: Towards a black Christology ${ }^{12}$}

The main theological interlocutor for Mofokeng in his very profound thesis from the early nineteen eighties is the world-renowned Swiss Reformed theologian, Karl Barth. ${ }^{13}$ The thesis reveals why he chooses Barth. If this is not a misrepresentation, the first motivation is not only the stature of Barth in theology in general and Reformed theology in particular, but also the matter of context. As much as Barth cannot be called a contextual theologian in the sense of 'modes of liberation theology', context plays an extremely important role in his life and theology. His socialist stance and identification with working class people in the village of Safenwil in Switzerland where he ministered a congregation, assisting to establish two trade unions for workers, have played a significant role in his theology. It is his break with liberal theology after the outbreak of the First World War, however, as well as his disillusionment with the Socialist Party, the church and theology, all of whom have supported the war, which might have interested Mofokeng mostly.

The second motivation for Mofokeng seemed to have been that despite the contextual nature of Barth's theology and his break with liberal theology as a legacy from the nineteenth century, he did not proceed far enough. In his own reflection, therefore, and in his very creative discourse on a black Christology of liberation, Mofokeng goes beyond Barth in creating hermeneutics that integrates ongoing participation in the struggle for liberation and theological reflection. Mofokeng's black theology is by definition a theology of praxis. This is what we now turn to.

\section{A black Christology of liberation}

Before proceeding to a description and analysis of Mofokeng's valuable proposal on a black Christology of liberation, it is important to be mentioned that Mofokeng not only engages Barth, but also Sobrino ${ }^{14}$ as one of his main theological interlocutors. In his thesis Mofokeng purports to go beyond both Barth and Sobrino as far as his Christology is concerned. In broad terms the difference between Barth and Sobrino on the one hand, and Mofokeng on the other hand, seems to be the following: Whereas the former two arrive indeed at a radical application of the story of

12 Takatso A. Mofokeng, The Crucified among the Crossbearers: Towards a black Christology, 1987.

13 Karl Barth, Church Dogmatics, 1st ed. (T\&T Clark, 1936, 1956, 1958, 1961, 1962).

14 Jon Sobrino, Christology at the Crossroads (Maryknoll, New York: Orbis Books, 1978). 
Jesus, the latter does not mere apply the story, but constructs hermeneutically an identification between the story of Jesus in his suffering and crucifixion and the story of poor, oppressed and suffering black people in South Africa. It would be more apt, therefore, to suggest that the real interlocutors for Mofokeng ${ }^{15}$ are not Barth and Sobrino, but the people he refers to right at the start of his thesis. These are people like the black farm worker who grieved and despaired, because he had very little to show during harvest time despite having toiled for the whole year. In Mofokeng's ${ }^{16}$ own words: 'He had laboured very hard for the whole year and it was harvest time. His employer, the farmer, was just full of smiles following the bumper harvest, but the black farm worker had got almost nothing to show to his wife and four kids as the fruit of his toils and tears.' This is the question that would haunt Mofokeng and indeed this is the question that informed his very creative construction of a black Christology of liberation.

We shall now turn to describing and analysing Mofokeng's black Christology. If Mofokeng ${ }^{17}$ is understood correctly, his construction of a black Christology of liberation was not meant as the be all and end all, as something so impressive that nothing else will ever rival it, but rather a 'relevant framework for Christological reflection' ${ }^{18}$ The starting point for Mofokeng is that his black Christology is a question of all questions. It is the question of Christ himself in asking his disciples, 'Who do you say that I am?', but it is simultaneously the question of a black subject, namely, 'Who am I?' and 'How can I be liberated to be my authentic self?' These questions are contained in one another, or to put it more concretely, the question of black people is contained in the question of Jesus about his own identity. In the construction of a black Christology, Mofokeng keeps the issue of identity and black people's quests for land inextricably connected to one another. In clear terms and in an attempt to keep love and justice in creative tension to one another, Mofokeng ${ }^{19}$ asserts that black people's struggle for 'justice in their socio-political and economic situation includes a struggle to recover the land'. The land issue is the second major dimension of Mofokeng's construction of a black Christology of liberation. This article does not allow space for a more extensive treatment of this particular dimension of Mofokeng's construct.

The exception, however, is some perceptive and insightful thoughts which Mofokeng borrows from Wielenga ${ }^{20}$ on God's solidarity with the poor in their struggle to reclaim and regain their dispossessed land as an expression of God's solidarity with the landless Israelite nomads. These are the people, according to Wielenga, with

15 Mofokeng, The Crucified, ix.

16 Mofokeng, The Crucified, ix.

17 Mofokeng, The Crucified, 227-263.

18 Mofokeng, The Crucified, 227.

19 Mofokeng, The Crucified, 230.

20 B. Wielenga, It's a long way to freedom (India: Tamilnadu Theological Seminary, 1981), 12-127. 
whom YHWH (which is one of the names for God in the Old Testament, referring specifically to his identity as Lord of the Covenant, an agreement between himself and the people of Israel) associates himself and also with their dream. That is the reason why he shows them the land; he promises them the land and gives it to them. Wielenga advances this as a strong theological argument for the defence of the land against imperialist dispossession. Any form of imperialist dispossession as well as a refusal to take possession of, or to defend the land, constitutes sin.

Mofokeng's third dimension in his black Christology is its grounding in a trinitarian theology. This is yet another creative discourse in the interplay between Reformed theology and black theology. There is no suggestion with Mofokeng, not even remotely so, to circumvent the trinitarian starting point. A black Christology of liberation is rooted in the sending of the Son by the Father. As Mofokeng ${ }^{21}$ contends: 'The Father and the Son live eternally in a relationship of love through the Holy Spirit. This is the relation in which the Father loves the Son eternally and the Son freely receives the love of the Father, thus loving him freely in return through the power of the Holy Spirit as the Spirit of the Father and the Son.' In interpreting incarnation as God's condescension in love to the creature that has fallen into conflict and suffering, Mofokeng ${ }^{22}$ grounds Christology in the trinitarian life of God, arguing that the liberation of man (sic.) is consequently grounded in the trinitarian life of God. Nothing is left to chance, in particular not the liberation of the oppressed and the creation of new human beings.

The fourth and most obvious dimension of Mofokeng's ${ }^{23}$ black Christology is its grounding in the life and work of Jesus, the Jew from Nazareth. For the construction of his own black Christology, Mofokeng draws, inter alia, from Boesak ${ }^{24}$ and Cone ${ }^{25}$ in their construction of the black Messiah and the black Christ respectively. The matrix for the life and work of Jesus is the conflicts between the poor and sinners on the one hand, and the religious, economic and political institutions and powerful forces, on the other. Mofokeng proceeds to contend that in that situation Jesus chooses the side of the victims of society by becoming a victim himself. This persistence in the praxis of the kingdom or reign of God results in the cross. Mofokeng asserts that Jesus consciously and willingly accepts the cross as a potent weapon to end suffering and to create a new humanity, as well as a new world. This in turn, namely, 'this history of suffering love ${ }^{26}$ is what frees the victims from passivity to participation in the struggle for a true humanity. It is this struggle which makes them cross bearers

21 Mofokeng, The Crucified, 242.

22 Mofokeng, The Crucified, 243.

23 Mofokeng, The Crucified, 15.

24 Boesak, 1976, 41-45.

25 James H. Cone, A black theology of liberation, 2nd ed. (Maryknoll, New York: Orbis Books, 1986), 119-128.

26 Mofokeng, The Crucified, 16. 
for a true humanity. The moment of identification between Jesus and the struggle for liberation is indeed a moment of the Crucified among the Crossbearers.

Ultimately the creative contribution of Mofokeng in bringing Reformed theology and black theology into discourse with each other is not so much the selection of themes or dimensions, but the emergence of hermeneutics that is grounded in praxis, facilitating the interplay between the praxis of liberation of black people in South Africa and the text of the Bible.

\section{L.W. Mazamisa: Beatific Comradeship. An Exegetical- Hermeneutical Study of Luke 10:25-3727}

\section{A story and a plot}

In a rather technical and sophisticated New Testament study on Luke 10:25-37, Mazamisa, ${ }^{28}$ engaging a number of literary theories as well as models of parabolic interpretation, identifies the Samaritan as the Irrupting Other and Comrade of God.

In contending that 'all life has the character of a story and plot', Mazamisa shows how all the events of the story from Luke 10:25-37 fall into a dramatic mould: A certain man goes down from Jerusalem to Jericho, and falls into the hands of robbers; a certain priest passes by on the other side without drawing near; correspondingly a Levite, who travels the same road (but a Samaritan) comes, sees, and is moved by compassion as he draws near. In his commentary on the unfolding drama Mazamisa ${ }^{29}$ states: 'These are sad but magnificent scenes which characterize the reality made flesh and blood and earth, embosoming and situating in the world of Jesus and the lawyer the possibility of God permeating it by becoming "Flesh" as Comrade of the afflicted in the person of a non-person and profaned Samaritan.'

\section{The Irrupting Other and Comrade of God}

Informed by Cloete' $\mathrm{s}^{30}$ notion of 'hemelse solidariteit' ('heavenly solidarity') in his Kampen thesis of 1980 which deals with the relationship between Christology and soteriology in John's Gospel, Mazamisa contends that God's mercy is essentially about entering human history as a human being to participate in human affairs. God allows himself to be loved in the person of the neighbour. In the parable of the Samaritan, the narrator himself emerges as 'the Parable within the parable'. In Mazamisa's interpretation, however, he also transcends the language-event.

27 Llewellyn W. Mazamisa: Beatific Comradeship. An Exegetical-Hermeneutical Study of Luke 10:25-37.1987.

28 Mazamisa: Beatific Comradeship, 163-175.

29 Mazamisa: Beatific Comradeship, 163.

30 Cloete, Hemelse Solidariteit, 1980. 
He dynamites, making it extremely powerful, and actualises the event. Indeed, according to Mazamisa, ${ }^{31}$ the Parable of God par excellence is also the Comrade of humanity par excellence on the basis of his incarnation. Mazamisa ${ }^{32}$ goes on to say the following about the incarnation:

The incarnation is the substantiation of the promissory covenanting of God. It unfolds as solidarity with historical human persons. This solidarity is not grounded in the metaphysical and apocalyptic ideological world, but in the world that resembles the world of the parable of the Good Samaritan where solidarity is translated into action. This parable touches the depth of life as it unveils its most vulnerable moment, forsakenness. It portrays on the one hand, the reason of forsakenness, which is the inability of the human person to descend into the depths where life is lifeless for the sake of the neighbour who is forced into a situation of lifelessness. The barrier which obstructs the movement of human to fellow human in the depths is the insatiable urge of human beings to move upwards, spiritually, economically, socially...

\section{S.P. Govender - In Search of Tomorrow: The dialogue between black theology and Marxism In South Africa ${ }^{33}$}

In the context of this article perhaps Govender could be seen as the odd one out, since his thesis is not even remotely engaging the encounter between Reformed theology and black theology. His thesis is included for description and analysis, however, since it attempts at enriching the discourses on black consciousness and black theology. The manner in which he tries to achieve the enrichment is by bringing black theology and Marxism into discourse with one another. Govender ${ }^{34}$ argues that a shift from Marxism in general or dogmatic Marxism to the evolvement of Marxist thinking through someone like Gramsci should facilitate the necessary dialogue between the two. The upside of this in his thesis is a fine analysis of Gramsci's thinking with reference to the significance of key concepts like hegemony, civil society, organic intellectuals, passive revolution, war of movement, subaltern, etc. The big deficit in the thesis, as far as the engagement with Gramsci is concerned, is that there is no clear creative moment or integrative moment between black theology and Gramsci.

In chapter five of his thesis Govender ${ }^{35}$ shows quite pertinently that for him the encounter between black theology and Marxism in South Africa is about the engagement of the former with socialist thought. In arguably one of the best comparisons between black theology in the United States and South Africa, he indicates how the two share the same historical and theological circumstances. He

31 Mazamisa: Beatific Comradeship, 172.

32 Mazamisa: Beatific Comradeship, 163.

33 S.P. Govender: In Search of Tomorrow. The dialogue between black theology and Marxism in South Africa, 1987.

34 S.P. Govender: In Search of Tomorrow, 65-74.

35 S.P. Govender: In Search of Tomorrow, 140-162. 
continues to argue that the manner in which black theology in the United States raises the issue of Marxism was bound to affect black theology in South Africa. Cone and West emerge in the thesis as Govender's main interlocutors, both who propose that Marxist social analysis can enrich black theology. Cone ${ }^{36}$ contends that such social analysis will assist in understanding the relation between economics and oppression in North America and throughout the world, and that liberation was not a process limited to black-white relations in the United States, but something to be applied to relations between rich and poor nations. West ${ }^{37}$ has called the new interest in Marxist thought as the fourth stage in the development of black theology in the United States. What is for Govender the particular challenge for black theologians in South Africa in the context of the encounter between black theology and Marxist thought? In his understanding the contribution is in the area of developing a counter-hegemonic culture by taking seriously Gramsci's thoughts on the role of organic intellectuals.

\section{In Search of Tomorrow: The triad of critical theory, critical history and critical theology}

In this framework Govender then continues to construct his triad of critical theory, critical history and critical theology as the distinct contribution of black theologians to the dialogue between black theology and Marxist social thought. The critical question Govender was grappling with in the late nineteen eighties, when his thesis was produced, is the following: Whether black consciousness ideologically as the bedrock of black theology was strong enough for the new level of struggle that was lying ahead. Govender contends that proponents of black theology at that time were grappling with the shifts and thrusts that were taking place in the context of resistance against apartheid. For him the new impulses emerging were opening up a new phase in the development of theological thinking in South Africa. In the context of his thesis he saw clearly the engagement with Marxist social thought as a source of redefinition of the theological mandate. Wary of a potential battle for supremacy between Marxist social thought and black consciousness, Govender ${ }^{38}$ proposes the type of dialectic between the two that would prevent black consciousness from being a false consciousness 'by which blacks existentially tried, and still try negatively and masochistically to sublimate their objective conditions of oppression' and unlocks the potential of Marxist theory to 'enlighten, explain and contextualise the phenomenon of black consciousness'.

36 James H. Cone, Black theology and the black Church. Where do we go from here? In Black theology. A Documentary History 1966-1979 edited by G.S. Wilmore and J.H. Cone (Maryknoll, New York: Orbis Books 1979), 357.

37 S.P. Govender, In Search of Tomorrow, 149.

38 S.P. Govender, In Search of Tomorrow, 153. 
In turning to the second constitutive element of his triad, Govender ${ }^{39}$ in his thesis chooses 'for a critical analysis of history based on the dialectical interplay of race and class in the political economy of South Africa'. He follows Sibidi ${ }^{40}$ in his use of the concept 'racial capitalism' as a manner of coming to grips with the South African reality as a racial oligarchy and a capitalist society. The most obvious omission here is of course the element of gender. In terms of the evolvement of consciousness the very sharp insight was gained that black women in South Africa were indeed subjected to a triple oppression in terms of race, class and gender. A parallel to this is what is currently viewed in South Africa as the unholy triad of inequality, poverty and unemployment. We shall return to this shortly.

For now, this part will be concluded with Govender's third constitutive element of his triad, namely critical theology. He sees a critical theology as a contextual theology that demythologises and liberates theology and exposes its ideological character. It is a theology rooted in the ability to respond creatively to the challenge of social and individual sin in an apartheid society. In specific reference to black theology, Govender ${ }^{41}$ identifies it as a critical theology which 'assists the communities of the faithful to speak and to hear the words of the Messiah, and it enables the oppressed in the midst of their suffering and in the joys of their acts of liberation also to experience the coming of the Kingdom'. Govender goes on to mention the Kairos Document as the clearest example of such critical theology.

\section{DOES THE CONSIDERATIONS OF THESE FOUR THEOLOGIANS HAVE ANY RELEVANCE FOR POST- APARTHEID SOUTH AFRICA?}

From the outset it is important to dwell briefly on what has been alluded to already, namely the difference in context between South Africa of the nineteen eighties and today. In modest terms, with the democratic 'revolution' of 1994 the country has seen a major breakthrough: South Africa is not what it was before. The negotiated settlement between political parties and the ensuing process around the Truth and Reconciliation Commission, however, have presented the country with a set of teasing circumstances which are now starting to haunt South Africa seriously. The ongoing violence, the unholy triad of inequality, poverty and unemployment, corruption of a very serious nature, crony politics and nepotism are but some of the challenges which bring the question of relevance, as far as the four theses are concerned, sharply in focus. In saying this, the second important issue here is the tricky question of the perceived redundancy of black theology. What sense will it still make to try and advance new forms of black theology? If indeed black theology

39 S.P. Govender, In Search of Tomorrow, 156.

40 Sibidi, 1986, 31.

41 S.P. Govender, In Search of Tomorrow, 161. 
has been unnerved in terms of the best case scenario and declared 'dead' in terms of the worst case scenario, is any question about the relevance of black theological ideas expounded in the nineteen eighties not entirely nonsensical?

\section{What is in a title?}

If the titles of the four theses under discussion are anything to go by, what they have set out to capture is, in a sense, more relevant now than in the nineteen eighties. The Cry for Life (Ntoane) of the Marikana miners, farm workers, young women assaulted, raped and murdered, millions of South Africans still suffering in the dungeon of disease, inequality, poverty and unemployment, pierce the South African atmosphere without ceasing. These are still the Crossbearers (Mofokeng) with whom the Crucified identify in their quest for the land, and $A$ better Tomorrow (Govender). Every now and then they are pleasantly surprised when the grace of $A$ Beatific Comradeship (Mazamisa) gets bestowed upon them.

\section{A quest for relevance}

An attempt will now be made to engage the question of relevance in a slightly more structured fashion. A number of issues come to mind: first, the constant need of theology towards liberation and transformation. In our context, anno 2013, where new 'Church and State theologies' seem to be emerging, there is a dire need to expose them as in the mid-nineteen eighties when these theologies came under severe criticism from the Kairos Document.

Second, in a context where the absorption power of neo-liberal capitalism has deformed comradeship into a type of neo-comradeship that is defined in terms of political access and upward mobility with the concomitant access to state tenders and contracts, the urgent need arises for deconstruction, to point out significantly how the state and the ruling party, by way of neo-comradeship, maintain false supreme values, while claiming democracy. It is of course grossly idealistic if not unrealistic to expect comradeship in a modern ruling party to be similar to comradeship in a liberation movement that was informed by selfless commitment to the struggle against apartheid, not to forget values like care for one another and trust. Yet, the need for the type of human solidarity which Mazamisa speaks of in his construct of a beatific comradeship is self-evident in South Africa.

Thirdly, South Africa as a very complex cultural, socio-political and socioeconomic reality is in constant need of a deeper analysis where Marx and Gramsci may appear to be slightly more relevant than during the nineteen eighties when Govender produced his thesis. The kairos, the opportune moment for something extraordinarily special, was then, but it is also now. Why does theology no longer allow itself to be informed by social analysis? In a democratic society where a 
diversity of ideas is on offer, the need to engage these from the perspective of critical theology is obvious.

Fourth, the lasting legacy of these theologians, by way of a fourth issue, for example, Ntoane, Mofokeng, Mazamisa and Govender, is the type of hermeneutics they created by bringing the context into critical discourse with the Bible and other sources in an ongoing circular or spiral movement. This is the type of hermeneutics that has kept the dream alive and rekindled hope. It is the kind of hermeneutics that facilitates a constant re-describing of reality towards renewal.

\section{LIST OF REFERENCES}

Barth, Karl. Church Dogmatics, 1st ed. T\&T Clark, 1936, 1956, 1958, 1961, 1962.

Boesak. 1976. Farewell to Innocence. Maryknoll, N.Y.: Orbis, 41-45.

Cloete. 1980. Hemelse Solidariteit. Kampen: Kok.

Cone, James H. 1979. Black theology and the black Church. Where do we go from here? In Black theology: A Documentary History 1966-1979 edited by G.S. Wilmore and J.H. Cone. Maryknoll, New York: Orbis Books, 357.

Cone, James H. 1986. A black theology of liberation, 2nd ed. Maryknoll, New York: Orbis Books, 119-128.

Govender, S.P. 1987. In Search of Tomorrow: The dialogue between black theology and Marxism in South Africa.

Mazamisa, Llewellyn W. 1987. Beatific Comradeship. An Exegetical-Hermeneutical study of Luke 10:25-37.

Mofokeng, Takatso A. 1987. The Crucified among the Crossbearers: Towards a black Christology.

Ntoane, L.R.K. 1983. A Cry for Life. An Interpretation of 'Calvinism' and Calvin, 1st ed.

Sobrino, Jon. 1978. Christology at the Crossroads. Maryknoll, New York: Orbis Books.

Sibidi, 1986. In Mosala, I, The unquestionable right to be free. Maryknoll, N.Y.: Orbis, 31.

Wielenga, B. 1981. It's a long way to freedom. India: Tamilnadu Theological Seminary, 12-127. 